\title{
Mediterranean spotted fever with involvement of the gastrointestinal tract
}

\author{
Maria João França Pereira, José Manuel Romãozinho, Carlos Sofia
}

Department of

Gastroenterology, Centro

Hospitalar e Universitário de Coimbra, Coimbra, Portugal

\section{Correspondence to}

Dr Maria João França Pereira, mariajoao.80@hotmail.com
To cite: Pereira MJF, Romãozinho JM, Sofia C. BMJ Case Rep Published online: [please include Day Month Year] doi:10.1136/ bcr-2013-200186

\section{DESCRIPTION}

A previously healthy 62 -year-old man, resident in a rural environment, was admitted to the intensive care unit of gastroenterology with a 5-day history of fever $\left(39^{\circ} \mathrm{C}\right)$, upper abdominal pain, nausea, emesis and cutaneous rash, complicated in the preceding day by haematemesis. Physical examination revealed a maculopapular rash in the trunk and palmoplantar regions. Laboratory data demonstrated ferropenic anaemia (haemoglobin $8 \mathrm{~g} / \mathrm{dL}$ ), thrombocytopenia $(34000 / \mu \mathrm{L})$, leukocytosis $\left(12.8 \times 10^{3} / \mu \mathrm{L}\right)$, elevated C reactive protein $(21 \mathrm{mg} / \mathrm{dL})$ and acute renal failure. The upper endoscopy showed fresh blood in the gastric lumen, multiple serpiginous erosions and several small shallow ulcers covered with haematin in the antrum and duodenum, one of them with active bleeding. Endoscopic haemostasis was made with epinephrine and the placement of four haemoclips. The duodenal biopsies revealed erosive duodenitis. The serology was positive for Rickettsia conorii. Therapy was performed with intravenous doxycycline and pantoprazole. The upper endoscopy, 7 days after, showed improved endoscopic lesions and no signs of recent haemorrhage (figures 1-3).

Mediterranean spotted fever (MSF) is a tickborne rickettsial disease caused by the infection with one of the two strains of $R$ conorii complexMalish and 'Israeli tick typhus', whose main vector and reservoir is the tick Rhipicephalus sanguineus. ${ }^{1}$ Clinically it is characterised by a generalised vasculitis process with the classic clinical triad of fever, rash and lesion at the site of tick bite (tache noire). ${ }^{2}$ Although the majority of cases are considered benign, in the past years severe forms of MSF have emerged, requiring intensive care facilities. ${ }^{3}$ The upper gastrointestinal haemorrhage is a rare complication of the disease and an atypical presentation. ${ }^{3}$ It has been previously described as MSF

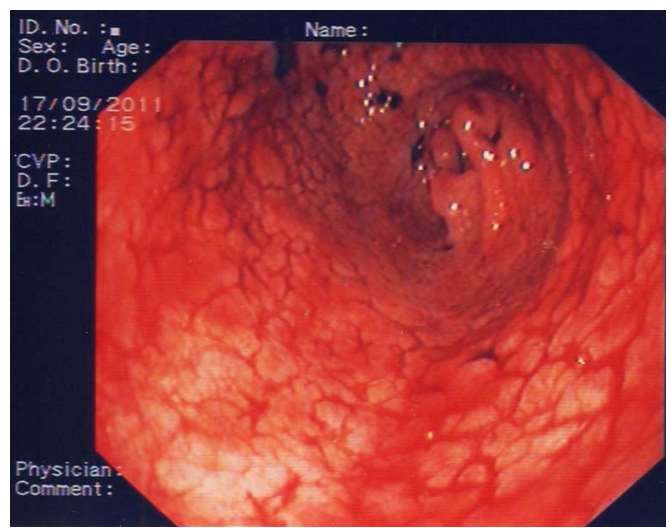

Figure 1 Upper endoscopy image: gastric antrum with multiple serpiginous erosions and several small shallow ulcers covered with haematin.

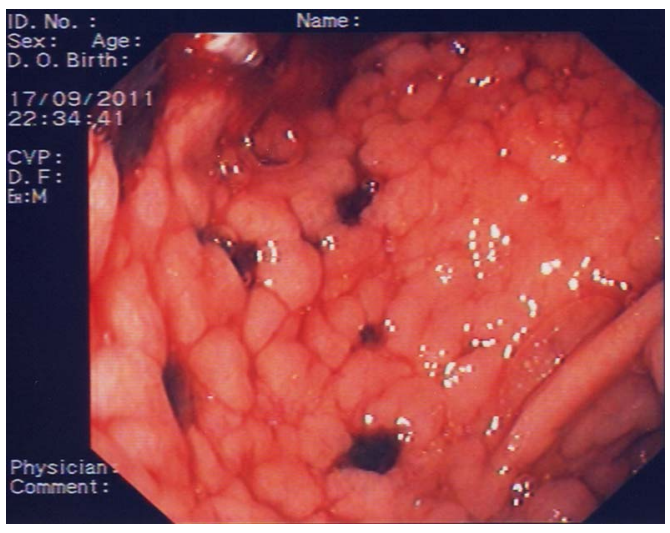

Figure 2 Upper endoscopy image: gastric antrum with multiple serpiginous erosions and several small shallow ulcers covered with haematin.

Olmer's haemorrhagic form. ${ }^{3}$ Rickettsial vasculitic process of injury in the upper gastrointestinal tract is histologically similar to that observed in other organs in patients with MSF and may manifest clinically as digestive tract bleeding. ${ }^{4}$

\section{Learning points}

- Mediterranean spotted fever is characterised by a generalised vasculitis process (classic clinical triad: fever, rash and lesion at the site of tick bite).

- The diagnosis is based on positive serological test for Rickettsia conorii complex.

- The rickettsial vasculitic process of injury in the upper gastrointestinal tract is histologically similar to that observed in other organs and may manifest as digestive tract bleeding.

- The gastrointestinal haemorrhage is a rare complication and an atypical presentation.

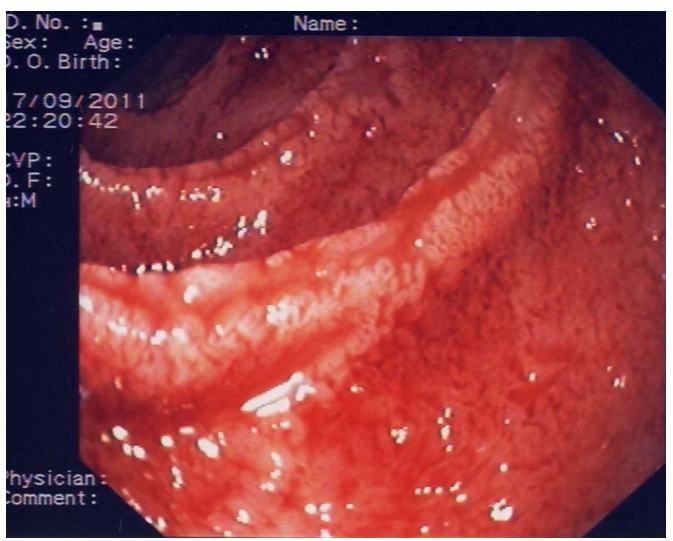

Figure 3 Upper endoscopy image: duodenum with serpiginous and diffuse erosions. 
Competing interests None.

Patient consent Obtained.

Provenance and peer review Not commissioned; externally peer reviewed.

\section{REFERENCES}

1 Rovery C, Brouqui P, Raoult D. Questions on Mediterranean spotted fever a century after its discovery. Emerg Infect Dis 2008;14:1360-7.
2 Sousa Rd, Nóbrega SD, Bacellar F, et al. [Epidemiologic features of Mediterranean spotted fever in Portugal.] Acta Med Port 2003;16:429-36.

3 Amaro M, Bacellar F, França A. Report of eight cases of fatal and severe Mediterranean spotted fever in Portugal. Ann NY Acad Sci 2003;990:331-43.

4 Ruiz-Beltrán R, Herrero-Herrero JL, Walker $\mathrm{DH}$, et al. Mechanisms of upper gastrointestinal hemorrhage in Mediterranean spotted fever. Trop Geogr Med 1990:42:78-82.

Copyright 2013 BMJ Publishing Group. All rights reserved. For permission to reuse any of this content visit http://group.bmj.com/group/rights-licensing/permissions.

BMJ Case Report Fellows may re-use this article for personal use and teaching without any further permission.

Become a Fellow of BMJ Case Reports today and you can:

- Submit as many cases as you like

- Enjoy fast sympathetic peer review and rapid publication of accepted articles

- Access all the published articles

- Re-use any of the published material for personal use and teaching without further permission

For information on Institutional Fellowships contact consortiasales@bmjgroup.com

Visit casereports.bmj.com for more articles like this and to become a Fellow 